Így hivatkozzon erre a cikkre:

Székely Iván. „A redős papsapkagomba és a tudásmenedzsment”. Információs Társadalom VII, 4. szám (2007): 162-164

A folyóiratban közölt müvek

a Creative Commons Nevezd meg! - Ne add el! - Így add tovább! 4.0

Nemzetközi Licenc feltételeinek megfelelően használhatók. 


\section{INFINIT HÍRLEVÉL}

Székely Iván

\section{A redós papsapkagomba és a tudásmenedzsment}

Az információ- és tudáskezelés látszólag elvont problémái néha nagyon is konkrét következményekhez vezetnek, triviálisnak túnó események pedig utólag elgondolkodtató kérdéseket vethetnek fel.

Még májusban történt, hogy Helsinkiben jártam, a híres halpiacon, ahol halakon kívül sok más is kapható, például kézmúves termékek és északi gyümölcsök, amelyeknek még neve sincs magyarul. A sok vonzó áru között megpillantottam egy láda gyönyörú, frissen szedett erdei gombát, olyat, amit addig soha nem láttam. Más turisták figyelmét is felkeltette, láttam, hogy érdeklődve mutogatnak a láda felé. Elég nagy tömeg volt az árusnál, aki mindenféle más zöldséget és gyümölcsöt is árult; mire közelebb férkốztem, láttam, hogy egy áthúzott kezet ábrázoló piktogram van egy táblácskára festve és a gombák közé szúrva. Gondoltam is, nyilván azért, hogy a sok turista ne fogdossa össze a szép árut.

Nagy gombakedvelố lévén, nem tudtam ellenállni a kísértésnek, és vettem egy kilót - majd beteszem a kézipoggyászomba és vigyázok rá, hogy másnap ne törjem össze hazafelé a gépen. A nagy papírzacskó gombához az árus adott is egy félbetépett A/4-es, halvány fénymásolatról fénymásolt papírt is, amit majdnem kidobtam, de megrögzött archivista lévén - betettem a gomba mellé. Egész nap alig mertem letenni a táskámat, nehogy baja essen a zsákmánynak - lesz otthon öröm és meglepetés...

Este a szállodai szobában megint majdnem kidobtam a kissé átnedvesedett papírfecnit, amikor észrevettem, hogy nyomtatott nagybetús szavak és hármas felkiáltójelek vannak rajta. Valami nem tetszett ezen a papíron. Finnül és svédül volt írva, egyikben sem vagyok járatos. Internetkapcsolat természetesen volt a szállodában (ráadásul ingyenes - Finnországban vagyunk), úgyhogy kiterítettem a gusztusos szerzeményt a szállodai ágyra, bekapcsoltam az úti notebookomat, és rászántam egy kis idốt, hogy megpróbáljak a svéd és finn szavak alapján valamilyen angol nyelvú eligazítást találni.

Találtam. Kiderült, hogy amit vettem, nem más, mint a gyilkos galócáéhoz mérhetố mérgezôségû́ gomba, amit a világ minden országában szigorúan tilos árulni, kivéve Finnországot. Van ugyanis egy komplikált méregtelenítési eljárás, ami után - ha sikerrel járunk - a gomba fogyaszthatóvá válik, mi több, igazi ínyencség. E nélkül viszont halálos: tönkreteszi a májat, a központi idegrendszert, és a gyanútlan fogyasztó szörnyú kínok között pusztul el. Bôrön át is felszívódik a mérge (most már értem a piktogramot), és a gốzei is mérgezók. Aki fejfájást és zavartságot érez a vele egy légtérben levő gomba társaságában, azonnal menjen friss levegóre vagy szellốztessen - írta az internetes jótanács. Amikor eddig jutottam az olvasásban, akkor jöttem rá, hogy már hosszú percek óta fáj a fejem a mellettem pompázó gombacsokor társaságában. Mást nem tudtam kita- 
lálni, bevágtam az árut a minibárba, hogy ott ontsa tovább mérgezó gớzeit, rohantam kezet mosni és feltéptem az ablakot - azaz csak feltéptem volna, mert biztonsági okokból csak a legfelső csíkját lehetett egy résre kinyitni.

Valahogy nem ébredtem nyugodtan és kipihenten... Reggel eldöntöttem, hogy nem viszem haza; ekkora kockázatot nem ér meg az egész. Pedig még az is eszembe jutott, hogy két nappal azelótt a mellettem vacsorázó brit professzor milyen élvezettel fogyasztotta a ... a kucsmagombát, ahogy ô gondolta. Valójában éppen azt a mérgező gombát ette, amit én is megvettem a piacon. Volt ugyanis angol nyelvú étlap is, és azon „morels" (kucsmagomba) szerepelt. A morels ugyan stimmelt, de angolul valójában „false morels”-ról, azaz hamis kucsmagombáról volt szó - nehogy összetévessze valaki az ehetố rokonával -, ezt az apróságot viszont az étlap elmulasztotta közölni. A méregtelenítés nyilván jól sikerült, mert a professzor azóta is jó egészségnek örvend, én meg nem világosítottam fel utólag a vacsora kalandértékéról. Már csak azért sem, mert a méreganyag esetleges maradványai nem ürülnek ki a szervezetból, hanem rendszeres fogyasztás esetén felhalmozódnak és rákkeltố hatásúak - jobb, ha nem aggódik.

A gombától pedig nem tudtam megszabadulni sehogy sem. Ha becsempészem egy szállodai szemétgyújtóbe, a kipárolgásával tovább mérgezi a környezetét. A parkban is szétszórhattam volna, de hátha valaki felszedi. Ha lehúzom a vécén, rossz rágondolni, mi van, ha eldugul tóle a csatorna és visszaöklendezi az árut. Végül nagy lélegzetet vettem, kivettem a csomagot a minibárból és kimentem vele a recepcióhoz. A kisasszonyhoz fordultam: ezt a pompás árut tegnap vettem a piacon, hogy hazavigyem, de közben rájöttem, hogy milyen komplikált az elkészítése - nem ajándékozhatnám-e meg ốt? Belenézett a csomagba, és kissé elkomorult: igen, ismeri, de ô nem tudja, hogy mit kell vele csinálni. Talán valamelyik ismerôse - próbáltam segíteni. Na jó, mondta végül komoly empátiával, és elvette a csomagot.

A történet itt véget is érhetne: minden jó, ha jó a vége - végül is nem irtottam ki senkit a környezetemben (bár ha meggondolom, nem sok híja volt). Az elgondolkodtató kérdések - ha úgy tetszik, a tudásmenedzsment-problémák - azonban most jönnek.

Ezt a gombát (Gyromitra esculenta, magyar neve: redős papsapkagomba) Kanada és Oroszország egyes részein, valamint a skandináv országokban hagyományosan méregtelenítik és fogyasztják, de árulni csak Finnországban szabad. A redôs papsapkagombát a finn konyha fugujának is nevezik, a Japánban elhíresült, fugu nevú halálosan mérgezô hal után, amelyet méregtelenítés után ínyencségként fogyasztanak.

Egy zárt tudásközösségben nyilván minden gyerek tudja, hogy ezt a gombát nem szabad leszedni, megfogni, majd késóbb azt is megtanulják, hogy hogyan lehet méregteleníteni és megenni. Ez a tudásközösség felbomlóban van. Bár Helsikiben feltehetôleg kevesebb olyan gyerek van, mint Budapesten, aki csak rezervátumban látott olyan egzotikus állatokat, mint a tyúk vagy a kecske, azért már itt sem nó fel mindenki a hagyományos tudás megszerzésének közegében. De ennél fontosabb a globalitás kontra lokalitás problémája: a helsinki piacon a világ minden részéról érkezett turisták tömegei vásárolnak, és legfeljebb annyi a közös tudásuk, hogy a piac vásárlásra való és a helyi termék mindig jó ajándék.

Kinek a felelőssége a hagyományos tudás megosztása? Milyen csatornákon kellene ennek történnie? A külvilág hogyan szelektáljon az információözönból? Valamilyen szabály nyilván van most is, ezért kaptam az írásos figyelmeztetést - finnül és svédül. 
Talán az útikönyvek szerkesztốinek kellene felhívniuk az utazó figyelmét az ilyen tudnivalókra? Az én bédekkeremben egy szó sem volt róla. Vagy mindenki tájékozódjon utazás előtt, leselkedik-e rá valamilyen speciális helyi veszély, skorpió, mérges pók vagy piacon árult mérges gomba? Esetleg főzés elốtt minden esetben nézze meg a Wikipediát? Japánban legalább fordított a helyzet: ott minden adag fuguhoz igazolást ad a szakács, hogy saját kezúleg méregtelenítette a halat. (Ennek ellenére minden évben van haláleset, és nemcsak a vendégek, hanem a szakácsok között is.)

Azért, visszatekintve, mégiscsak volt valami az egész információs folyamatban - a nagybetúk, valami stílusbeli szokatlanság, az internet, a Wikipedia - ami esetemben megoldotta a problémát. Lehet, hogy a bimbózó tudástársadalom és a benne szocializálódó turisták viselkedésmintázatai valahogy kipótolják a hiányzó láncszemeket a megszakadt információs múveletekben.

Remélhetóleg ebbe a láncba most már újabb elem épült be az Olvasó számára - és azt is remélem, hogy a probléma felkeltette az érdeklődését. Az enyémet mindenesetre felkeltette, legközelebb lehet, hogy éppen redôs papsapkagombát rendelek egy megbízható helsinki vendéglóben.

\section{Ajánlott irodalom}

Általános tudnivalók:

http://en.wikipedia.org/wiki/False_morel

Elkészítése, megrögzött ínyenceknek:

http://www.dlc.fi/ marianna/gourmet/morel.htm

Rövid magyar ismertető:

http://www.gombanet.hu/gomba.php?gid=80 